Bartın University Journal of Faculty of Economics and Administrative Sciences, 2021, Volume 12, Issue 24

\title{
Covid-19 Salgınının Uluslararası Yatırım Uyuşmazlıklarının Çözümü Süreçlerine Etkisi ${ }^{1}$
}

\author{
Dr. Öğr. Üyesi Beyza ÖZTURANLI ŞANDA \\ Bartın Üniversitesi İktisadi İdari Bilimler Fakültesi, Siyaset Bilimi ve Kamu Yönetimi \\ bozturanli@bartin.edu.tr, OrcID: 0000-0003-4184-5563
}

\section{$\ddot{O} z$}

Dünya çapında bir yılı aşkın süredir devam eden Covid-19 salgını, devletleri benzeri görülmemiş önlemler almaya zorlamakta, tam kapanmalar yanında, seyahat yasakları, ek vize gereklilikleri, tıbbi ürünlerin ithalat ve ihracatına getirilen kısıtlama ve yasaklar, sağlık hizmetlerinin kamulaştırılması, projelerin yavaşlatılması gibi tedbirler yabancı doğrudan yatırımları kaçınılmaz olarak etkilemektedir. Devletlerin salgınla mücadele sürecinde aldığı önlemler, uluslararası yatırım andlaşmalarının ihlali iddialarını gündeme getirebilecek ve bu iddialar, yatırımcıların sınır ötesi ticari faaliyetlerinin ulusal düzeyde karşılaştı̆̆ı engellerden kaynaklanan uyuşmazlıkların bağımsız ve tarafsız yargı organlarınca çözümünü temin etmek amacıyla faaliyet gösteren, kurumsal tahkim mekanizmaları önünde devletlere karşı ileri sürülebilecektir. Yeni dönemde Covid-19 salgını ile mücadele etmek amacıyla alınan ve yabancı doğrudan yatırımları etkileyen ulusal tedbirlerin, uluslararası yatırım uyuşmazlıklarının çözümüne ilişkin hukuki rejime etkisi önem arz etmektedir.

Anahtar Kelimeler: Salgın, uluslararası yatırım hukuku, yatırım uyuşmazlıklarının çözümü

JEL Sınıflandırmaları: F21, F34, K33

\footnotetext{
1 Özet metni, 20-22 Mayıs 2021 tarihleri arasında sanal ortamda düzenlenen I. Uluslararası Gümrük ve Ticaret Kongresinde bildiri olarak sunulmuştur.

APA: Özturanlı Şanda, B. (2021). Covid-19 Salgınının Uluslararası Yatırım Uyuşmazlıklarının Çözümü Süreçlerine Etkisi. Bartın Üniversitesi İktisadi ve İdari Bilimler Fakültesi Dergisi, 12 (24), 376-399. APA: Özturanlı Şanda, B. (2021). The Effect of The Covid-19 Epidemic on International Investment Dispute Settlement Processes. Bartın University Journal of Faculty of Economics and Administrative Sciences, 12(24), 376-399.
} 


\title{
The Effect of The Covid-19 Epidemic on International Investment Dispute Settlement Processes
}

\begin{abstract}
The worldwide outbreak of Covid-19, which has been going on for more than a year. Governments have had to take unprecedented measures around the world, including complete lockdowns, travel bans, additional visa requirements, restrictions and prohibitions on the import and export of health products, temporary expropriation of health services, slowing down projects inevitably have impact on foreign direct investments. Those measures taken by the host-states in order to combat with the Covid19 pandemic, can bring up the allegations of violation of international investment treaties that the claims of investors might be the subject of various disputes before the arbitral institutions against governments which operate in order to ensure the resolution of disputes arising from the national obstacles faced by investors' transboundary commercial activities. The impact of the national measures taken by the governments to prevent the spread of disease to legal regime related to the investment dispute settlement becomes more of an issue in the new era.
\end{abstract}

Keywords: Epidemic, international investment law, investment dispute settlement

JEL Classification: F21, F34, K33

\section{Giriş}

Bir sağlık krizi olarak ortaya çıkan ve bir yılı aşkın süredir devam eden Covid-19 salgını, dünya genelinde milyonlarca insanın ölümüne ${ }^{2}$ ve hemen her sektörde ciddi ekonomik risklerin doğmasına neden olmuştur. Kamu sağlığına yönelik büyük bir tehdit olması yanında, ekonomiler üzerindeki sarsıc1 etkisi, hükümetleri virüsün yayılmasını önlemek amacıyla seyahat kısıtlama ve yasakları, ek vize gereklilikleri, sağlık ve gıda ürünlerinin ithalat ve ihracatına getirilen kısıtlama ve yasaklar, sağlık hizmetlerinin geçici olarak kamulaştırılması gibi pek çok tedbir almaya itmiştir. Birleşmiş Milletler Ticaret ve Kalkınma Konferansı (UNCTAD) verilerine göre, 2020 yılı içinde devletlerin aldığı yatırım politikaları tedbirleri, 2019'a oranla ikiye katlanmıştır (UNCTAD/WIR/2021: XI).

Bunun yanı sıra, salgın küresel düzeyde yabancı doğrudan yatırımların sayısının 2020 yılı içinde çarpıcı bir şekilde düşmesine neden olmuştur. Küresel ekonomik büyümenin motoru olarak görülen uluslararası üretimi ciddi şekilde etkileyen kriz, en çok da sanayi ve alt yapı projelerinde sıfırdan yatırım (greenfield investment) gibi en kazançlı yatırım türleri üzerinde olumsuz etkisini göstermiştir. Ayrıca ulusal güvenlik mülahazalarına dayanarak yabancı doğrudan yatırımlara yönelik tarama

${ }^{2} 12$ Ağustos 2021 itibariyle Dünya Sağlı Örgütü (WHO) verilerine göre dünya genelinde 4.323.139 kişi Covid-19 nedeniyle hayatını kaybetmiştir. (https://covid19.who.int/) 
mekanizmalarının giderek artan şekilde kullanımı nedeniyle, sınırlayıcı politikalara dayalı tedbirlerin sayısı tarihinin en yüksek oranına ulaşmıştır (UNCTAD/DIAE/PCB/INF/2021/2: 2)

Bununla birlikte, bugün yürürlükte iki binden fazla uluslararası yatırım andlaşması bulunmakta, bu andlaşmalar uluslararası yatırımlara ilişkin hukuki rejimin ilk adımını oluşturarak, ev sahibi devlet ile yabancı yatırımcı arasındaki hukuki ilişkiyi düzenlemektedir. $^{3} \mathrm{Bu}$ andlaşmalar, ev sahibi devletin, yabancı yatırıma halel getirebilecek türden keyfi, ayrımcı ve adaletsiz devlet politikalarına karşı yatırımcının haklarını korumayı amaçlamaktadır. Yapılış koşulları, ev sahibi devletlerin ekonomik ve sosyal statüleri, devletlerin doğal kaynaklarından faydalanma hakları gibi farklı değerlendirmelere tabi tutulabilecek olan bu andlaşmalar, neticede ev sahibi devlet ile yatırımcı arasındaki ilişkilere hukuki kesinlik kazandırmaktadır.

Yatırım andlaşmalarından kaynaklanan uyuşmazlıkların uluslararası tahkim yoluyla çözümüne ilişkin hukuki alt yapıyı kendi anayasaları ile temin eden devletlerin salgın sürecinde aldıkları tedbirlerin uluslararası tahkim organları önünde yargılama konusu olması bu sürecin son derece doğal bir sonucudur. Bununla birlikte, yabancı doğrudan yatırımlardan kaynaklanan uyuşmazlıkların çözümüne ilişkin hukuki rejimin, devletin egemen yetkilerini giderek kısıtladığı da bir vakıadır (Dolzer, 2016: 953; Fry \& Repousis, 2016: 795; Brower \& Schill, 2008: 497) . Uluslararası yatırım andlaşmalarının uygulanmasından doğan uyuşmazlıkların çözümünü üstlenen, uluslararası kuruluşlar ya da barolar nezdinde veyahut tamamen ad-hoc nitelikteki hakem mahkemelerinin yetkisini sınırlayan genel bir hukuki çerçeve bulunmamaktadır. Mevcut hukuki çerçeve, bölgesel düzeyde veya iki devlet arasında akdedilen yatırımların korunması ve teşviki andlaşmalarını, ev sahibi devlet ile andlaşma konusu hizmeti ifaya talip olan yabancı yatırımcı arasında akdedilen iki ya da çok taraflı yabancı doğrudan yatırım andlaşmalarını, ilgili devletlerin yabancı yatırımların tabi olacağı rejimi düzenleyen iç hukuk normlarını, ilgili devletlerde yatırımların işleyişi sürecini etkileyebilecek, öngörülebilen ya da öngörülemeyen siyasi, ekonomik ve sosyolojik vakıalardan güçlü şekilde etkilenen, geleneksel uluslararası kamu hukukunun arzu edilen normatif yapısından uzak bir sistemi düzenlemeye çalışmaktadır.

Böyle hukuki ve siyasi öngörülebilirlikten uzak bir sistem içerisinde uluslararası yatırım uyuşmazlıklarının çözümü rejimi, Covid-19 salgını ile mücadele eden hükümetlerin, yabancı doğrudan yatırımlara yönelik aldığı ve alacağı tedbirler karşısında, yatırımcılar tarafından harekete geçirilecektir. Uluslararası yatırım uyuşmazlıklarının çözümü süreçlerinin bu sürece nasıl yanıt vereceği önem kazanmaktadır.

$\mathrm{Bu}$ çalışmada, Covid-19 salgını ile mücadele etmek amacıyla alınan ulusal tedbirlerin uluslararası yatırımları ne derece etkilediği, kamusal mülahazalara dayalı

\footnotetext{
${ }^{3} 12$ Ağustos 2021 tarihi itibariyle UNCTAD verilerine göre yürürlükte 2290 iki taraflı yatırım andlaşması bulunmaktadır (https://investmentpolicy.unctad.org/international-investmentagreements)
} 
The Effect of The Covid-19 Epidemic on

olarak alınan devlet tedbirlerinin hukuki olarak nasıl temellendirilebileceği, tedbirler karşısında yabancı yatırımcıların muhtemel iddialarının hukuki temeli ve bütün bu unsurların, uluslararası yatırım uyuşmazlıklarının çözümü rejimine etkisi değerlendirilmiştir.

\section{Covid-19 Salgını ile Mücadelede Yabancı Doğrudan Yatırımlara Yönelik Devlet Tedbirleri}

UNCTAD verilerine göre, sadece, Mayıs 2020 - Aralık 2020 döneminde 52 devlet ve Avrupa Birliği (AB) yatırım politikalarına ilişkin 96 farklı tedbir almış ve yeni hukuki düzenlemeler getirmiştir ki yatırım kısıtlamalarına ilişkin bu oran neredeyse son yirmi yılın en yüksek oranıdır (UNCTAD/DIAE/PCB/INF/2021/2: 1). Önde gelen gelişmiş, gelişmekte olan devletler ve Çin, Kore Cumhuriyeti ve Rusya Federasyonu gibi geçiş ekonomisine sahip devletler, yabancı doğrudan yatırımlara ilişkin hukuki ve siyasi mekanizmalarını geliştirmeye başlamışlardır. Bunlardan bazılarının amacı, yabancı kontrolüne karşı hassas iç ticareti korumak iken; bazı devletler tamamen sektörel bazda politikalar uygularak, hastaneler, klinikler, laboratuvarlarda sunulan sağlık hizmetlerinin yanı sıra, bunların sunulması için gerekli personel ve bilgi teknolojisi alt yapı hizmetlerini de içerek şekilde yabancı yatırımlara ilişkin hukuki alt yapılarını gözden geçiren düzenlemeler getirmişlerdir (UNCTAD/WIR/2021: 138).

Kimi devletler, genel olarak ticari hayatı etkileyen önlemler almış, örneğin Meksika, yenilenebilir enerji sektöründe kesintilere gitmiş, Peru otoyol ve köprü geçiş ücretlerinin ödemelerini askıya almış, Çin Telif Hakkı Yasasında değişiklik yaparak, telif hakkı sahiplerinin konumunu güçlendirmiş; Vietnam, işletmelerin tescil prosedürünü basitleştirmiş ve fikri mülkiyet başvuru sahiplerinin yasal temsilcilerine yönelik yasal gereklilikleri arttırmış; Zambiya, stratejik bir değer olarak altın ticaretine ilişkin madencilik kurallarını değiştirmiş; Angola, Arjantin, Kongo, Kenya, Birleşik Tanzanya Cumhuriyeti ve Vietnam vergilendirmeye ilişkin normatif düzenlemeleri değiştirmiştir (Sanderson, 2020). UNCTAD verilerine yansımamakla birlikte pek çok Latin Amerikalı hükümet, temiz suya erişim amacıyla faturalara yansıyan vergileri azaltmış, faturanın ödememesi nedeniyle su hizmetlerinin aksamasını önleyecek tedbirler almıştır (Chitapain, 2021). Yeni düzenlemeler ve kısıtlayıcı yatırım politikası önlemleri, esas olarak olağanüstü bir kriz durumundan kaynaklanmaktadır ve bu nedenle devletlerin yabancı yatırımlar politikasında kalıcı bir değişiklik yaratmak amacı taşımamaktadır.

Bununla beraber salgın sürecinde, özellikle sağlık sektöründeki yabancı yatırımlara yönelik tedbirlerin sayısında önemli bir artış olduğu göze çarpmaktadır. Dünyanın muhtelif coğrafyalarından 70 devlet üzerinde (24'ü gelişmiş, 41 'i gelişmekte olan ve 5'i geçiş ekonomisini haiz devletler) UNCTAD tarafindan yürütülen izleme çalışmaları sonucunda, bu devletlerin neredeyse üçte birinin salgın başlangıcından bu yana, sağlık sektöründeki yabancı yatırımcılara yönelik tarama usullerini yaygınlaştırdığı ve güçlendirdiği tespit edilmiştir (UNCTAD/WIR/2021: 134). 
Yatırımların taranması ifadesi, ev sahibi devletin, kamu düzeni ya da ulusal güvenlik gibi gerekçelere dayanarak, yabancı doğrudan yatırımları değerlendirmesi, soruşturması, yetkilendirmesi, koşullandırması, yasaklaması ya da faaliyetlerini yavaşlatmasına izin veren prosedürleri işaret etmektedir. Schill devletin yabancı doğrudan yatırımlara ilişkin böyle kamusal yetkilerini kullanmasını "yatırım tarama paradoksu" olarak ifade etmektedir (Schill, 2019: 109). Gerçekten de, içe dönük yatırım akışının temel amacı yabancı pazarlarda gelecekte yatırımların daha özgürleşmesi iken, yeni bir yabancı doğrudan yatırımların taranması mekanizmasının getirilmesinin ilk etkisi, yabancı yatırımlar üzerindeki kontrolü daha da sıkılaştırmak, bu nedenle de onları sinırlamaktır.

Örneğin, AB'nin de içinde olduğu 18 gelişmiş ekonomiyi haiz devlet, ulusal güvenlik gerekçesine dayalı olarak özellikle sağlık sektöründe yabancı yatırımları neredeyse bloke edecek tarama mekanizmalarını kabul etmiştir. (World Investment Report 2021, table III.6). Gelişmekte devletlerden 13'ü ise yerel yatırımcıların sektöre katkısını teşvik etmek amacıyla, farmakolojik üretim ve biyoteknoloji alanında, 9'u medikal malzeme üretimi alanındaki yabancı yatırımcıların sektöre girişini zorlaştıran tedbirler almıştır. 6 gelişmekte olan devlet ise tıbbi hizmet veren bazı alt sektörlerdeki yabancı yatırımcıların ülkeye girişini yasaklamıştır (UNCTAD/WIR/2021: 136).

Mevcut tarama mekanizmalarına bakıldığında, ya salgın nedeniyle sağlık sektörüne özel tarama mekanizmaları şeklinde (Örneğin Macaristan, İtalya, Polonya, Slovenya ve İspanya) veyaulusal güvenlik gerekçesiyle, mevcut tarama mekanizmalarının sağlık sektörünü içerecek şekilde genişletilmesini içeren tarama mekanizmaları şeklinde (Çin Halk Cumhuriyeti ve Amerika Birleşik Devletleri); veyahut (Güney Afrika Cumhuriyeti, Nikaragua ve Laos'ta olduğu gibi) kamu sağlığına ve ulusal güvenliğe karşı tehdit oluşturduğu gerekçesiyle bazı yabancı yatırımları sınırlayan bir takım önlemler şeklinde uygulamaya konulduğu göze çarpmaktadır (UNCTAD/WIR/2021: 138).

Genel kapsamlı yatırımların korunması ve teşvikine ilişkin uluslararası yatırım andlaşmalarına bakıldığında ise spesifik sektörlere ilişkin yatırım sınırlamalarına işaret edilmemekle birlikte, salgından sonra yürürlüğe giren pek çok iki taraflı veya yabancı doğrudan yatırım andlaşmaları, sağlıkla ilgili konularda ev sahibi idareye takdir hakkı tanıyacak şekilde kaleme alınmaktadır. Aslında bugün yürürlükte olan yatırımların korunması ve teşviki andlaşmalarının \%90’1 1959-2011 yılları arasında yürürlüğe girmiştir. Oysa yeni nesil yatırımların korunması ve teşviki andlaşmalarının, sağlık ve ulusal güvenlik konularında ulusal makamların düzenleyici yetkisini tanımaya daha meyilli olduğu söylenebilir. (UNCTAD/WIR/2021: 145). Daha yakın tarihte yürürlüğe giren ve aşağıda daha ayrıntılı değerlendirilen yatırım andlaşmalarında, kamu sağlığı amacıyla alınan tedbirlerin kamulaştırma sayılmayacağını belirtildiği; kamu sağlığı amacıyla alınan tedbirlere ilişkin istisnai hükümler koyulduğu, andlaşmaların Preamble kısmında kamu sağlığını korumak konusundaki idarenin takdir yetkisinin öneminin vurgulandığı; idarenin takdir hakkını tanıyan klozların korunduğu; kamu sağlığını korumak amacıyla alınabilecek tedbirlere ilişkin tahkim iddialarını dışarıda bırakacak 
ya da bu konuda atanacak bilirkişi raporlarının yatırımcı-devlet uyuşmazlıklarının çözümü süreçlerinde dikkate alınmasını sağlayacak hükümler eklendiği bir vakıadır.

Yeni nesil yatırımların korunması ve teşviki andlaşmaları, yabancı yatırımların korunması ile idarenin düzenleyici yetkileri arasındaki dengeyi yeniden sağlayarak, sağlık alanında ev sahibi devletlere, andlaşmadan kaynaklanan taahhütlerini ihlal etmeden, yatırımların artması ve kolaylaşması için esneklik tanımaktadır. Böylelikle hem ev sahibi devletin düzenleme yetkisi güvence altına alınmakta, hem de sektörel bazda yabancı yatırımcıların ülkeye girişine verilen izinlere ilişkin hükümler ayrıntılı olarak düzenlenmektedir. (UNCTAD/WIR/2021: 145)

Yatırımların teşviki ve korunması andlaşmaları her ne kadar sağlık alanındaki yatırımları şekillendirse de, salgın nedeniyle alınan ve yukarıda özetlenen ad-hoc devlet tedbirleri bu süreçte daha çok öne çıkmaktadır (Kowalski, 2020: 132). Dolayısıyla ulusal sağlık sistemleri ve politikalarının karşı karşıya olduğu Covid-19 salgını gibi büyük krizlerin etkisini hafifletmek için alınan tedbirler, kaçınılmaz olarak, yürürlükteki uluslararası yatırım andlaşmalarından kaynaklanan yükümlülükler ile çelişecek ve yatırım uyuşmazlıklarının doğmasına neden olacaktır

\section{Covid-19 Salgını ile Mücadelede Alınan Tedbirlerden Kaynaklanan Uyuşmazlıkların Çözümüne İlişkin Hukuki Rejim}

Bugün yürürlükte olan binlerce yatırımların korunması ve teşviki andlaşması, geniş anlamda ev sahibi devlet ile yatırımcı arasındaki hukuki ilişkiyi düzenlemek ve dar anlamda yatırımcıları, keyfi, ayrımcı ve adaletsiz devlet politikalarına karşı korumak amacında olan sözleşmeler olup, yatırımcılara, devletlere karşı bağımsız hakem mahkemeleri önünde tahkim yargılaması süreçlerini başlatmak ve belki de ulusal hukuk sistemi içerisinde elde edemeyecekleri tazminatı devletten talep etmek yetkisi vermektedirler (Schmidt, 2020). Net bir hukuki çerçevesi olmayan yabanc1 yatırımlardan kaynaklanan uyuşmazlıkların çözümüne ilişkin hukuki rejime yöneltilen en büyük eleştirilerden biri, kamusal çıkarların korunması gerekliliği söz konusu olduğundan ev sahibi devletlere hareket alanı bırakılmamasıdır (Fry ve diğ., 2016: 808; Guntrip, 2016: 830; Brower ve diğ., 2008: 497).

Ancak uluslararası yatırım andlaşmalarından kaynaklanan uyuşmazlıkların uluslararası tahkim yoluyla çözümüne ilişkin hukuki alt yapıyı kendi anayasaları ile temin eden devletlerin salgın sürecinde aldıkları tedbirler, kaçınılmaz olarak uluslararası tahkim organları önünde yargılama konusu olabilecektir. Uluslararası yatırım andlaşmaları vesilesi ile işlev gösteren hakem mahkemelerinin yetkisini sınırlayan genel bir hukuki çerçevenin yokluğunda, devletin egemen yetkilerini kullanmasını içeren işlemlerine "paralel adalet sistemi" tarafından müdahale edilmesini sağladığı ve küresel ekonomik faaliyetten elde edilen karın adil paylaşımına katkı sağlamadığı eleştirileriyle de kimi zaman karşılaşan uluslararası yatırım uyuşmazlıklarının çözümü rejimi (Davitti ve diğ., 2020), Covid-19 salgını ile mücadele eden hükümetlerin aldığı ve yatırımları etkileyen önlemler karşısında yatırımcıların çalacağı ilk kapı olacaktır. 
Henüz Covid-19 salgını nedeniyle alınan tedbirlerden kaynaklanan bir uyuşmazlığa ilişkin olarak tefhim edilen bir yargı kararı olmamakla beraber, 2019 yılında Uluslararası Yatırım Uyuşmazlıklarının Çözümü Merkezi (ICSID)'e kaydedilmiş 39 yatırım uyuşmazlığı varken, 2020 yılında bu sayı 58'i bulmuştur. ${ }^{4}$ Elbette bu verileri değerlendirirken yatırım uyuşmazlıklarına ilişkin tahkim süreçlerinin gizli tutulabileceğini de hesaba katmak gerekmektedir.

Yatırımcıları koruyan hukuki düzenlemelerin sağladığı imkana dayanarak tahkim süreçlerinin başlatılmasına yönelik çalışmalar sürerken, kimi sivil toplum kuruluşları da bu zorlu süreçte devletlerin sürekli tahkim talepleri ile karşılaşması ihtimalini bertaraf etmek amacıyla öneriler sunmaktadırlar. 2020 yılı sonlarında insan hakları odaklı UlusÖtesi Şirketler ve Diğer Ticari Teşebbüsler Hükümetler-arası Çalışma Grubunun, ticaret ve insan hakları ilişkisi konulu bağlayıcı andlaşma hazırlanmasına yönelik ikinci gözden geçirilmiş taslağı yayınlanmıştır. Yeni taslağın önemli unsurlarından biri, kamu iktisadi teşebbüslerinin "ticari faaliyetler" tanımı içerisine açıkça dahil edilmesidir. Benzer şekilde andlaşma kapsamı tanımlanırken, "sözleşme ilişkisi” yerine "ticari ilişki" kavramına atıf yapılmış, ikametgah devleti mahkemelerine mağdurların kökenine bakılmaksızın yargı yetkisini kullanması yetkisi tanınması önerilmiş; ve yeni ticaret ve yatırım anlaşmalarının bu Taslağa ve ilgili devletin taraf olduğu insan hakları sözleşmelerine uygun olması gerekliliği ifade edilmiştir (OEIGWG, 2020: Art. 14/5). Benzer şekilde Uluslararası Sürdürülebilir Kalkınma Enstitüsü'nün, iki taraflı, bölgesel/uluslararası yatırım andlaşmaların hazırlanmasına rehberlik etmek üzere hazırladığı başka bir taslak, devlet-yatırımcı tahkim süreçlerinin askıya alınmasına ilişkin hükümler içermektedir (IISD, 2020). Yine 2020 yılı sonunda Afrika Birliği nezdinde kabul edilen "Covid-19 Salgını Tedbirlerine İlişkin Yatırımcı Devlet Uyuşmazlıklarının Çözümü Risk Bildirisi” çerçevesinde ev sahibi üye devletlere, muhtemel yatırım tahkimi iddiaları karşısında ahlaki ve siyasi destek verilmesi kararlaştırılmıştır. Zira olağan koşullarda bile ev sahibi devletlerin, özellikle gelişmekte olan devletler perspektifinden bakıldığında, yatırım tahkimi iddialarına cevap vermesi, hukuki ve siyasi koordinasyonu temin ederek yargılama sürecine hazırlanması hatırı sayılır bir zaman almaktadır (Danish, 2021:2).

Yatırım tahkimi iddialarının ertelenmesi taleplerinin hakem mahkemelerince dikkate alınması konusu ise yakın zamanda Daimi Hakem Mahkemesi nezdinde görülen Glencore Finance v. Bolivia davasinda ad-hoc hakem mahkemesi, ev sahibi devletin, yargılamanın Covid-19 salgının yarattığı olağanüstü zorlayıcı koşullar nedeniyle askıya alınması talebini, "silahların eşitliği”" ilkesini gerekçe göstererek reddetmiş, bunun yerine Bolivya hükümetine, karşı delil sunması için birkaç aylık ek süre vermiştir (Glencore Finance v. Bolivia, Procedural Order No. 10, 2020).

\footnotetext{
${ }^{4}$ Muhtelif hakem mahkemeleri önündeki derdest davaların konuları, tahkimde gizlilik ilkesine dayanarak dava dokümanlarının yayınlanmaması nedeniyle şuanda bilinmemektedir (https://www.lexology.com/library/detail.aspx?g=311b482c-7acd-4948-9c7a-a6c079425b84)
} 
Covid-19 salgını bağlamında henüz karara bağlanmış bir tahkim yargılaması olmamakla birlikte, Covid-19 nedeniyle alınan ulusal tedbirlerden kaynaklanan uyuşmazlıkların hakem mahkemeleri önünde çözümü süreçleri, yabancı doğrudan yatırımlar söz konusu olduğunda devletin ulusal yetkilerinin kapsamı da bir kez daha tartışmaya açılacak; hakem mahkemelerinin kamu sağlığı ve yabancı yatırımcıların sözleşmeden kaynaklanan hakları arasındaki seçimlerinin hukuki gerekçesi bu konuda yeni teamül kurallarının doğmasına da neden olabilecektir.

\section{Yabancı Yatırımcıların Hakları: İkili Yatırım Antlaşmalarındaki Yatırımların Korunmasının Hukuki Dayanağı}

\subsection{Eşit ve Adil Muamele Standardının İhlali}

Yatırımcıların Covid-19 nedeniyle alınan devlet tedbirleri karşısında konumlarını güçlendirebilecek nitelikteki eşit ve adil muamele standardı, pek çok uluslararası yatırım andlaşmasında bulunan, usule ve esasa ilişkin konularda yatırımcıyı koruyan, Türkçe literatürde hak ve nasafet derecesinde muamele yükümlülüğü olarak da anılan bir ilkedir (Çal, 2009: 108). Amacı, ev sahibi devletin benzer durumda bulunan yerli ve yabancı tüm yatırımcılara ve yatırımlara eşdeğer şekilde davranmasını garanti altına almaktır (Giray, 2013: 142). Esasa ilişkin olarak eşit ve adil muamele standard1, yatırımcıyı, ölçüsüz, adaletsiz ve ayrımcı devlet tedbirlerine karşı korur. Dolayısıyla devletlerin aldığ 1 Covid-19 tedbirleri, yatırımcı tarafından, alınan tedbir ile kamusal menfaat arasındaki orantısızlık nedeniyle ölçüsüz olarak değerlendirilebilir.

İki taraflı yatırım andlaşmaları da tazminatsız kamulaştırmaya karşı yatırımcıyı koruyan muhtelif hükümler içermektedir. Mesela sağlık hizmetlerinin kamulaştırılması, uzun süren kapanmalar nedeniyle yabancı yatırımcıların iş hayatını askıya almaya zorlanması kamulaştırma iddialarının gerekçesini oluşturabilir. Bununla birlikte çoğu hakem mahkemesinin kamu çıkarları söz konusu olduğunda, bu tedbirler kimi durumlarda dolaylı kamulaştırma anlamına gelse de, devlet yanlısı karar verme eğilimindedir. Mesela 2008 mali krizi sırasında bazı devletlerin aldığ 1 tedbirler hakem mahkemelerine taşınmış, davacının yatırım yaptığı bankadaki devlet katılımının artırılmasından kaynaklanan uyuşmazlığın çözümüne yönelik Marfin v. Cyprus, davasında hakem mahkemesi, ev sahibi devletçe alınan ve çoğunluk hisselerin kamulaştırılması, yönetim kurulundaki üyelerin üyeliklerinin kaldırılması ve bankaların yeniden sermayelendirilmesini içeren tedbirlerin hukuka aykırı kamulaştırma olmadığına, devletin ekonomik kriz sırasındaki mali sisteminin sağlıklı şekilde ayakta tutulmasını sağlamaya yönelik olarak getirilen, iyi niyetli düzenlemelerin uygulanmasını içeren ayrım gözetmeyen ve ölçülü tedbirler olarak nitelendirilebileceğine karar vermiştir (ICSID Case No. ARB/13/27, 2018: 828). Benzer şekilde Teinver v. Argentina davasında hakem mahkemesi, yatırımcının yatırım yaptığ 1 dönemde Arjantin'deki yıkıcı ekonomik koşulları bilerek yaptığı yatırımın, adil ve eşit muamele standardı ilkesinden faydalanamayacağı kararına varmıştır (ICSID Case No. ARB/09/1, 2017: 667). Aynı yorum salgın etkileri sürerken yapılan yatırımlar için de yapılabilir. 
İyi niyetli olmayan, yatırımcıların yatırımlarını elinden alma amacını taşıyan, ölçüsüz ve ayrımcı tedbirlerin devletin uluslararası hukuktan kaynaklanan sorumluluğuna neden olacağı söylenebilir. Bu nedenle alınan tedbirlerin bağlamı, ilgili zaman diliminde elde edilen veri ve bilgi dahilinde tedbirlerin zamanlaması, yatırımcının davranışı ve devletin vis a vis yatırımcıya karşı yükümlülüklerinin spesifik kapsamı, devletin sorumluluğunu belirlenmesinde dikkate alınmalıdır.

Bu noktada söz konusu devlet tedbirlerinin kamusal niteliğini ispat eden önemli bir husus, devletin bu tedbirleri alma sürecinde yatırımcı ile ilişkilerindeki şeffaflığıdır. Eğer devlet, kamu denetimi ya da kamuoyu görüşüne başvurmayı sağlayacak hukuki düzenlemelerin politikaları gündemine alırken paydaşlar ile istişarelerde bulunursa, devletin söz konusu politikalarının rasyonel olup olmadığı değerlendirmesi yapılabilecektir (Borman, 2020). Böylelikle ev sahibi devletin doğrudan yabanc1 yatırımcılar ile istişare taleplerine katılma istekliliği göstermeyen yatırımcıların bu tutumları, tedbirin adilliğine ilişkin şikayetlerinin hakem mahkemesince değerlendirilmesinde dikkate alınacaktır.

\subsection{Kamulaştırma Yasağının İhlali}

Devletlerin egemen yetkilerine ilişkin teamül hukukunun da bir parçası olarak kabul edilen Birleşmiş Milletler (BM) Genel Kurulu'nun 14 Aralık 1962 tarihli 1803 sayılı "Doğal Kaynaklar Üzerinde Sürekli Egemenlik" başlıklı Kararında Devletlerin egemenlik haklarından biri olan kamulaştırmanın "uygun bir tazminat" ile "kamu yararı, güvenlik veya ulusal çıkar" gerekçesiyle gerçekleştirilebileceği hükme bağlanmıştır. Karara göre, yerli ya da yabancı kaynaklı bireysel veya özel çıkarlar karşısında tamamen üstün kabul edilen kamu yararı, kamu güvenliği gibi ulusal çıkarlar söz konusu olduğunda, yürürlükteki ulusal ve uluslararası hukuk kurallarına uygun olarak mal sahibine uygun tazminat ödenir. Ödenmesi gereken tazminatın miktarı ya da şekli konusunda anlaşmazlık çıkması halinde öncelikle -ve uluslararası teamül hukuku kuralları gereği- bu türden önlemleri alan Devletin ulusal yarg1 yolları tüketilmelidir. Ancak, egemen devletlerin ve diğer ilgili tarafların mutabakatı üzerine, böyle bir uyuşmazlığın halli için tahkim veya uluslararası yargı yoluyla gidilebilir (UN General Assembly, A/RES/1803-XVII).

Benzer şekilde Türkiye Cumhuriyeti Anayasası'nın 46./1 maddesine göre, "Devlet ve kamu tüzel kişileri; kamu yararının gerektirdiği hallerde, gerçek karşılıklarını peşin ödemek şartıyla, özel mülkiyette bulunan taşınmaz malların tamamını veya bir kısmını, kanunla gösterilen esas ve usullere göre, kamulaştırmaya ve bunlar üzerinde idarî irtifaklar kurmaya yetkilidir". Benzeri pek çok gelişmekte olan devlet anayasasında görülebileceği üzere, 1982 Anayasasına 1999 yllında giren hükme göre, kamu hizmetleri ile ilgili imtiyaz şartlaşma ve sözleşmelerinde bunlardan doğan uyuşmazlıkların milli veya milletlerarası tahkim yoluyla çözülmesi öngörülebilir. Milletlerarası tahkime ancak yabancılık unsuru taşıyan uyuşmazlıklar için gidilebilir" (1982 Anayasas1, Md. 125/1). 
Kamulaştırma yetkisi uluslararası yatırım andlaşmalarında da ayrıntılı olarak düzenlenmektedir. Mesela Türkiye ve İsrail arasındaki Yatırımların Korunması ve Teşviki Andlaşmasına göre, taraf devletlerden birinin yatırımcılarının diğer diğer tarafın ülkesindeki yatırımları, kamu yararına olmadıkça, ayrımcı olmayacak biçimde yapılmadıkça, ilgili yasa hükümleri takip edilmedikçe ve anında, yeterli ve etkin tazminat ödenmedikçe devletleştirilmeyecek, kamulaştırılmayacak ya da devletleştirme ya da kamulaştırma etkisi olan tedbirlere maruz bırakılmayacaktır. Kamulaştırmadan etkilenen yatırımcılar, işlemi gerçekleştiren taraf devletin kanunları çerçevesinde işlemin kendisinin ya da kamulaştırma bedelinin ilgili tarafın yetkili mahkemelerinde hemen değerlendirilmesini isteme hakkına sahiptir. ${ }^{5}$

Bütün bu hukuki çerçeve dikkate alındığında, özel hastanelerin kamulaştırması, tıbbi ekipmana el konulması veya tıbbi ürünlerin ithalat ya da ihracatının yasaklanması gibi doğrudan ya da dolaylı kamulaştırma sonucunu doğuran diğer kısıtlamalar karşısında yabancı yatırımcılar, yatırımlarının doğrudan veya dolaylı olarak ilgili ev sahibi devlet tarafından hukuka aykırı bir şekilde kamulaştırıldığı, yatırımlarının adil ve eşit muameleye tabi tutulmadığı gerekçesiyle, zararlarının giderilmesi için uluslararası tahkim süreçlerini başlatabilirler. Her ne kadar hakem mahkemeleri, kamusal çıkarları değerlendirirken yatırım andlaşmalarını ev sahibi devlet lehine yorumlamaya eğilimli olsalar da; aşağıda daha ayrıntılı açıklanacağı üzere, bazı devlet tedbirleri dolaylı kamulaştırmaya karşıllı gelmekte, bu nedenle hakem mahkemeleri tarafindan, korumacı ekonomi politikaların karar alma mekanizmalarını ne derece etkilediği sorgulanmaktadır (S.D. Myers, Inc. v. Canada, Partial Award, 2000: 162).

\subsection{Ev Sahibi Devletlerin Covid-19 ile Mücadele Kapsamında Aldıkları Önlemlerin Hukuki Dayanağı}

\subsection{1 İki ve Çok Taraflı Yatırım Andlaşmaları Kapsamında Öngörülen İstisnalar}

Hepsi olmamakla birlikte, yukarıda da değindiğimiz bazı modern iki taraflı yatırım andlaşması modelleri, kamu sağlığı gibi hususlarda ev sahibi devletlere istisnai düzenlemeler yapma yetkisi veren ve devleti sorumluluktan kurtaran hükümler içermektedirler. Elbette devletlerin ikili ilişkilerinde bu model andlaşmalara ne kadar bağlı kalacakları kendi takdirlerine kalmaktadır. Ancak model andlaşmaları, ev sahibi devlet-yatırımcı menfaatlerini dengeleme kapasitesi bakımından tarafların ilişkilerine şeffaflık getirmektedir. Mesela 2009 tarihli Türkiye BIT modelinde, ev sahibi devletin düzenleme yetkisine ilişkin hüküm altında, andlaşma hükümlerinin, taraf devletlerin savaş ve diğer olağanüstü hallerde ayrımcı olmayan tedbirler almasını engellemeyeceği düzenlenmektedir. Yine Türkiye ile İsveç arasındaki uluslararası yatırım andlaşmasına göre, ilgili taraf devletin ülkesinde savaş, silahlı çatışma, iç karışıklık, seferberlik hali veya diğer benzer olaylar nedeniyle zarar gören taraf devletlerden her birinin

\footnotetext{
5 Türkiye Cumhuriyeti Hükümeti ile İsrail Devleti Hükümeti Arasında İmzalanan "Yatırımların Karşılıklı Teşviki ve Korunmasına İlişkin Anlaşma'nın Onaylanması Hakkında Karar”, Resmi Gazete Tarih: 03.03.1998/ Say1: 23275, Md. 5.
} 
yatırımcıları, diğer tarafça herhangi üçüncü bir ülke yatırımcılarına uygulanan muameleden daha az elverişli olmayacak şekilde, en elverişli muameleye tabi tutulacaklardır. Böyle durumlarda yapılması gereken ödemeler gecikmesiz olarak ve serbestçe transfer edilebilmelidir. ${ }^{6}$

Benzer şekilde 2019 tarihli Belçika-Lüksemburg Ekonomik (BLEU) Birliği yatırım andlaşması gibi bazı yatırımların korunması andlaşmalarının Preamble kısımlarında, andlaşma hükümlerinin, hiçbir şekilde taraf devletlerin meşru politikalar izlemek, halk sağlığı, çevre ve genel ahlakın korumak gibi amaçlarla tedbirler almak, bu tedbirleri sürdürmek ve uygulamak hakkı ile kamu güvenliğinin sağlanması, sürdürülebilir kalkınma hedeflerine ulaşılması, tüketicinin korunması, çalışma standartlarının korunması; mali sistemin bütünlüğü ve istikrarı veya kültürel çeşitliliğin teşviki ve korunması amaçlarına yönelik olarak tasarrufta bulunmak yetkisini sınırlayacak şekilde yorumlanamayacağı belirtilmektedir (Belgium-Luxembourg Economic Union Model BIT, 2019). Yine İtalya ve Kanada hükumetlerinin 2020 ve 2021 tarihli model yatırım andlaşmaları, taraf devletlerin insan haklarının korunması, kamu sağlığı, kamu güvenliği, çevrenin korunması, ekonomik istikrar, tüketicinin korunması, kültürel çeşitliliğin korunması gibi meşru amaçlarla düzenleme yapma haklarının saklı tutulduğuna ilişkin hüküm içermektedirler (Canada Model BIT 2021; Italy Model BIT, 2020). Bu model andlaşmalar ile uyumlu yatırım andlaşmaları, yürürlükte oldukları süre içinde ve sahibi devletlerin düzenleyici işlemler yapabilmesini sağlamaktadır. Bu doğrultuda Kanada, 31 Temmuz 2020'de Sanayi Bakanlığı nezdinde Bazı Kanun ve Yönetmelikler Tarafından Belirlenen Süre Sınırlamaları ve Diğer Sürelere İlişkin Kararnameyi kabul etmiş ve 31 Temmuz 2020 ve 31 Aralık 2020 arasında bildirilen yatırımlar için Yatırım Düzenlemelerinin ulusal güvenlik çerçevesinde gözden geçirilmesine izin veren sürelerini uzatmıştır. ${ }^{7}$

Başka bir örneği teşkil eden ve dolaylı kamulaştırma meselesini ayrıntılı olarak tanımlayan Hollanda Model Yatırım Andlaşmasına göre, taraf devletlerin, kamu sağlığı, kamu güvenliği, genel ahlakın ve çevrenin korunması ile kültürel çeşitliliğin korunması ve artırılması gerekçesiyle aldığı iyi niyetli, ayrım gözetmeyen ve ölçülülük ilkesine uygun tedbirler, dolaylı kamulaştırma teşkil etmeyecektir (Netherlands Model Investment Agreement, 2019: Art. 2/1). Benzer hükümler, Japonya ve Kore arasındaki 2002 tarihli yatırım andlaşması (Korea-Japan Investment Agreement, 2003: Art. 10/2) ve ABD ile Meksika ve Kanada arasındaki 2019 tarihli çok taraflı yatırım andlaşmasında bulunmaktadır (United States-Mexico-Canada Agreement-USMCA, 2020: Annex 14-B.3/b). Yine yakın zamanda yürürlüğe giren Çin ve Türkiye arasındaki yatırımların korunması ve teşviki andlaşması, bahsi geçen istisnai halleri, "etkin ve

\footnotetext{
${ }^{6}$ Türkiye Cumhuriyeti ile İsveç Krallığı Arasında İmzalanan "Yatırımların Karşılıklı Teşviki ve Korunması Anlaşması'nın Onaylanması Hakkında Karar", Resmi Gazete Tarih: 03.03.1998/ Sayı: 23275, Md. 4/2.

${ }^{7}$ Government of Canada, "Temporary Extension of Certain Timelines in the National Security Review Process Due to COVID-19", 31 July 2020, (https://investmentpolicy.unctad.org/investment-policy-monitor/measures/3547/temporarilyextends-timelines-for-fdi-screening)
} 
The Effect of The Covid-19 Epidemic on

yeterli tazminatın ödenmesi halinde" kamulaştırma yasağının istisnası olarak düzenlenmiştir (Agreement Between Turkey-China, 2020: Art. 5/2).

İki ya da çok taraflı yatırım andlaşmalarındaki ayrıntılı istisnai hükümler, Covid19 salgını ile mücadele kapsamında alınan tedbirlerden kaynaklanan yatırımc1 iddialarının hakem mahkemesi önünde ev sahibi devlet lehine değerlendirilmesine dayanak oluşturabilecektir. Covid-19 salgınının, ev sahibi devlete, kamu sağlığı ya da kamu düzeninin ya da kamu güvenliğinin korunması çerçevesinde düzenleme hakkı verip vermeyeceği meselesi, hakem mahkemelerince somut olayın koşullarına bağlı olarak değerlendirilebilecektir. $\mathrm{Bu}$ değerlendirmede, ev sahibi devletin salgınla mücadeleyi doğru yönetmesi, iyi niyetli davranması ve ayrım gözetmemesi dikkate alınması gereken önemli ölçütlerdir. ${ }^{8}$ Bununla birlikte bahsi geçen kamusal çıkarların korunması amacına yönelik olarak alınan tedbirlerin amacı ve yoğunluğu dikkate alındığında, iyi niyet ve ayrım gözetmeme ilkelerine uygun olarak değerlendirilebilen tedbirler, dolaylı kamulaştırma teşkil etmemelidir (Ostrove ve diğ., 2020). Zira yukarıda görüldüğü üzere iki taraflı yatırım andlaşması modelleri, bizatihi bu durumu, istisnai hüküm olarak işaret etmektedirler.

\subsubsection{Uluslararası Teamül Hukuku Çerçevesinde Devletin Sorumluluğunu Ortadan Kaldıran Haller}

\section{a) Mücbir sebep (force majeure)}

Mücbir sebep, hem iç hukuklarda hem de uluslararası hukukta, öngörülemeyen ya da karşı konulamayan ve zarara neden olan, kişinin iradesi dışındaki bir olayı belirtmektedir ve böyle durumlarda yükümlülüğünü yerine getirmeyen uluslararası hukuk kişisi sorumlu olmayacaktır. Uluslararası teamül hukuku çerçevesinde devletin uluslararası yükümlülükleri ile uyumlu olmayan, ancak mücbir sebepten ileri gelen fiilinin hukuka aykırılığının ortadan kalktığı kabul edilir (Pazarcı, 2013: 424).

BM Uluslararası Hukuk Komisyonunun hazırladığı, bugün uluslararası teamül hukukunun bir parçası olarak kabul edilen Devletin Hukuka Aykırı Fiillerinden Kaynaklanan Sorumluluğuna İlişkin Nihai Taslak Maddelerine göre, devletin kontrolü dışında, karşı konulamaz bir gücün veya öngörülemeyen olayların ortaya çıkması, uluslararası yükümlülüğün yerine getirilmesini fiziksel olarak imkânsızlaştıran durumlardır. Böyle durumlarda yükümlülügünü yerine getiremeyen devlet, uluslararası sorumluluktan kurtulmaktadır. Ancak hukuka aykırı fiilden kaynaklanan zarar, tek

\footnotetext{
${ }^{8}$ Uluslararası yatırım andlaşmalarında hükme bağlanan, ev sahibi devletlerin kamulaştırma yasağ1, iki türlü kamulaştırmayı ihtiva etmektedir. Bunlar, ev sahibi devletin özel mülkiyette bulunan taşınmaz malların mülkiyetini idareye cebren geçirilmesi anlamına gelen doğrudan kamulaştırma (Gözübüyük, 2013, 992) ve yatırımcının mülkiyet hakkına dokunulmamakla birlikte, hakkın kullanımına muhtelif kısıtlamalar getirilen dolaylı kamulaştırmadır (Baklacı, 2008: 9). Dolaylı kamulaştırma yasağının ihlaline ilişkin yargısal değerlendirmeler için bkz. Serafín García Armas and Karina García Gruber v. Bolivarian Republic of Venezuela, PCA Case No. 2013-3, Final Award, 26 Apr. 2019 (https://www.italaw.com/cases/2869).
} 
başına ya da diğer faktörlerle birlikte, mücbir sebebe başvuran devlet yüzünden doğmuşsa veya devlet, ortaya çıkan durumun riskini açıkça ya da zımnen üstlenmişse, artık mücbir sebebe başvurulamayacaktır (ILC Final Draft Articles, 2001: Art. 23).

Covid-19 salgını, her kadar öngörülemez ve karşı konulamaz bir durumdan kaynaklansa da, devletlerin yükümlülüklerini yerine getirmelerinin fiili imkansızlığını kanıtlamaları zor görünmektedir. Bu elbette somut olayın özelliklerine ve söz konusu yatırım andlaşmasından kaynaklanan spesifik yükümlülüğe göre değişecektir. Zira Covid-19 salgınından önceki dönemlerdeki değerlendirmelerinde uluslararası mahkemeler, sözleşmelerin ifası edilmemesinin gerekçesi olarak mücbir sebebe dayalı savunmaları oldukça az örnekte kabul edilebilir bulmuştur. Örneğin, Uluslararası Ticaret Odasının (ICC) 2003'te yayınladığı ve devletlerin yatırım andlaşmalarının formülasyonunda kullanabilecekleri "force majeure clause" önerilerini içeren raporunda, mücbir sebep halini, taraflardan birinin kontrolü dışında ve öngörülemeyen, olağan olarak sakınılamayan ve üstesinden gelinemeyen bir olayın vuku bulması halini içeren bir elverişsizlik standardı olarak tanımlamıştır. Bununla birlikte ICC, mücbir sebep oluşturan olayların andlaşmada sayılmasının, bu olayların ortaya çıkması halinde devletin sorumluluğundan kendiliğinden kurtulabileceği sonucunu doğurmayacağını da eklemiştir. Zaten geçmiş yargılamalar da göstermektedir ki devletlerin uluslararası yükümlülüklerini yerine getirmemelerinin gerekçesi olarak mücbir sebebe dayalı savunmaları çoğu durumda reddedilmektedir (Augenblick \& Rousseau, 2012: 60). Ancak mücbir sebebe ilişkin önerisini Covid-19 salgını döneminde biraz daha detaylandıran ICC, yatırım andlaşmalarının taraflarının, andlaşmaların formülasyonunda, mücbir sebep oluşturan olayları da içerecek şekilde "salgın, doğal afetler vb." şeklinde uzun formatlı istisnai hükümler kullanabilecekleri gibi; belirli bir sektöre has istisnai durumları düzenleyen kısa formatlı mücbir sebep hükümlerinin andlşamalara konulabileceği şeklinde görüş belirtmiştir (ICC Force Majeure Clause, 2003: 9).

Oldukça ağır ve öngörülemeyen bir seyirde ilerleyen Covid-19 salgınının, tarafların kontrolü dışında olma ve öngörülememe koşullarını karşılayarak, bir mücbir sebep olarak hakem mahkemelerince kabul edilip edilmeyeceği bu anlamda belirsizdir. Tarafların salgın süreçlerini nasıl yönettikleri ve taraflar arasındaki somut andlaşmanın hükümleri hakem mahkemelerinin değerlendirmelerini büyük ölçüde etkileyecektir. Günümüz koşullarında salgın kaynaklı ekonomik zorlukların öngörülebilirliği değerlendirildiğinde, mahkemelerin mücbir sebep gereklerini değerlendirme eşiği de yükselecektir (Kiraz\&Üstün, 2020). Bu durumda ekonomik zorluğun boyutuna bakılmaksızın, taraflar somut yatırım andlaşmasının hükümlerine bağlı kaldığı sürece ortaya çıkan riskin taraflar arasında paylaştırılması bir seçenek olabilir (Firoozmand \& Zamani, 2017: 410). Sözleşmenin hazırlanması sırasında, sadece mücbir sebep kaynağ1 olaylar listesi yazmak yerine, muhtelif olayların muhtemel etkilerinin andlaşma hükümlerinde yer alması bir başka seçenek olarak değerlendirilebilir. Örneğin bir salgın hastalıktan veya öngörülemeyen başka bir nedenden kaynaklanan "karantina" ifadesi, açıktır ki tarafların sözleşme kapsamında yükümlülüklerinin bir parçası olan iş gücünün de karantinaya gireceği anlamına geldiğinden, yükümlülüklerini yerine getirememesine 
gerekçe oluşturabilecektir (Augenblick \& Rousseau, 2012: 74). Covid-19 salgını ile mücadele süreci, ayrıntılı mücbir sebep hükümleri içeren andlaşmaların gerekliliğini ortaya koymuştur. Elbette andlaşmaların hazırlanma aşamasında pazarlık süreçlerinin yönetiminde taraflar arasında hukuki-siyasi bir dengenin gözetilmesi her zaman mümkün olmayacaktır. Ancak şu da bir gerçektir ki, yatırım andlaşmalarındaki geleneksel mücbir sebep hükümlerinin yargı organlarınca yorumlanmasında tespit edilen gerekliliklerin bu somut olayda karşılanması zor görünmektedir.

\section{b) Zaruret hali (necessity)}

Uluslararası Hukuk Komisyonunun Devletlerin Hukuka Aykırı Fiillerinden Dolayı Sorumluluğuna İlişkin Taslak Maddelerine göre, ağır ve çok yakın bir tehlikeye karşı, temel bir çıkarı korumak amacıyla başka türlü davranma imkanı olmayan devlet, ilgili devlet ya da devletlerin temel çıkarları ya da bir bütün olarak uluslararası toplumun temel çıkarları ciddi şekilde zarar görmemek şartıyla, uluslararası yükümlülüğüne aykırı fiilinden dolayı sorumlu olmayacaktır (ILC Final Draft Articles, 2001: Art. 25). Her halde zaruret hali, eğer söz konusu uluslararası yükümlülüğün bizatihi kendisi, zaruret haline başvurma ihtimalini bertaraf ediyorsa veya devlet, zaruret halinin oluşmasına katkıda bulunmuşsa, hukuka aykırılığı ortadan kaldıran meşru bir neden olarak kabul edilmemektedir (Wexler, 1987: 389-412). Uluslararası Adalet Divanı Gabcikovo-Nagymaros davasında uzun vadede etkisini sürdüren bir tehlikenin "yakın" olarak nitelendirilebilmesi için söz konusu zamanda tehlikeyi somutlaştıran unsurların kaçınılmaz ve kesin olarak ortaya çıkması gerekliliğini aramıştır ki Covid-19 salgınına yönelik önleyici tedbirler bu kapsamda değerlendirilebilir (ICJ, Gabčíkovo-Nagymaros Project, Judgment of 25 September 1997: 54).

Dolayısıyla bu noktada taraflar arasındaki yatırım andlaşmasının istisnai hallere ilişkin hükümleri yeniden önem kazanmaktadır. Andlaşmanın kendisi bu durumları dışarıda bırakmışsa devletin zaruret haline dayalı savunması mahkemece reddedilecektir. Yine salgınla mücadele eden devletlerin söz konusu zaruret halinin oluşmasına katkıda bulunup bulunmadığı (örneğin yayılımı önlemek için aşılama konusunda özen yükümlülüğüne uygun davranıp davranmadığı gibi) yine somut olayın özelliklerine ve ihlal edilen yükümlülüğün, ağır ve muhakkak bir tehlikeden kurtulmak için tek yol olup olmadığını üzerinden yapılacak değerlendirmeye tabi olacaktır.

Covid-19 salgınının küresel düzeyde dünya nüfusuna karşı ciddi bir hayati tehlike yaratmış olduğu gerçeği karşısında, "ağır ve yakın bir tehlike" olduğu değerlendirmesi yapılabilir. ${ }^{9}$ Ancak belirli bir devletin esaslı çıkarlarına yönelik bir tehdit mi yoksa bütün bir uluslararası topluma yönelik mi olduğu konusu tartışmaya açık olacaktır. Örneğin devletlerin halklarının esenliği devamı veya kamu hizmetlerinin sürmesi amacıyla aldığı tedbirler, ad-hoc hakem mahkemesi önünde görülen National Grid v. Argentine tahkiminde, yine Uluslararası Hukuk Komisyonunun Taslak

\footnotetext{
${ }^{9}$ Dünya Sağlık Örgütü (WHO) 30 0cak 2020'de Covid-19'u Public Health Emergency of International Concern (PHEIC), 11 Mart 2021'de ise pandemi ilan etmiştir.
} 
Maddelerine atıf yapılarak "esaslı menfaatlerden" olarak kabul edilmiştir (National Grid plc v. The Argentine Republic, 2008: 245).

Öyleyse salgınla mücadele sürecinde alınan devlet tedbiri, başka bir devletin ya da bir bütün olarak uluslararası toplumun esaslı menfaatlerine ciddi bir zarar vermemelidir. Yatırımcı-devlet uyuşmazlıklarında hakem mahkemeleri, bir devletin halkının esenliğine ilişkin menfaatinin, yatırımcıların (ya da yatırımcıların devletlerinin) menfaatlerine baskın geldiğini son yıllarda kabul etmektedirler. Elbette spesifik olarak Covid-19 tedbirlerinin yatırımcıların esaslı menfaatlerine ciddi zarar verip vermediği hususu, her somut olayda hakem mahkemelerince tartışılacaktır. Ancak Saluka v. Czech Republic davasını karara bağlayan hakem mahkemesinin önemli bir saptamasını hatırlamak gerekmektedir: "Hiçbir yatırımcı, yatırım yaptığı tarihteki koşulların sürekli sabit kalmasını beklememelidir. Yabanc1 yatırımcıların beklentilerine halel getirilmesinin meşru ve makul olup olmadığını tespit edilirken, ev sahibi devletin kamusal çıkarlara ilişkin ulusal meseleleri düzenleme konusundaki meşru hakkının olduğunun dikkate alınması gerekmektedir" (Saluka v. Czech Republic, Partial Award, 2006: 66).

Bununla birlikte, salgınla mücadelede alınan devlet tedbiri, ağır ve çok yakın bir tehlikeye karşı ve temel bir çıkarı korumak için uygun olan tek yol niteliğindeyse ancak meşru görülebilecektir. Tehlikeden korunmak için yükssek maliyetli ve uygulanması zor olmakla beraber alternatif olarak başvurulabilecek başka tedbirler varsa, öncelikle bunların kullanılması gerekliliği, hakem mahkemelerince aranabilir. Böyle yüksek bir standardın karşılanıp karşılanmadığ 1 , başvurulan tedbirin ağırlığ 1 , ifa edilmeyen yükümlülüğün bununla bağlantısı ve tedbirin alındığı zamanki tablo dikkate alınarak değerlendirilecektir. Devletin içinde bulunulan duruma katkısının olmaması gerekliliği değerlendirmesinde ise bazı mahkemeler, devletlerin "iyi niyetli fakat eksik tasarlanmış politikalarını" yeterli saymakta, devletin planlı ve kasıtlı olarak durumun vahametine katkıda bulunmuş olmasını aramamaktadır (Impregilo S.p.A. v. Argentine Republic, 2011: 353-356). Ancak ekonomik kriz nedeniyle ev sahibi devlet tarafindan alınan olağan üstü önlemlerin yargılama konusu olduğu bir davada ise hakem mahkemesi, krizin hem iç hem dış unsurlardan kaynaklanmış olmasının, devletin buna katkıda bulunduğunu kanıtlamaya yeterli olmadığına, devletin katkısından bahsedebilmek için, ekonomi politikalarını belirlerken bunun krizle sonuçlanacağını da bilinmesi gerektiğine karar vermiştir (Urbaser S.A. and Consorcio de Aguas Bilbao Bizkaia, Bilbao Biskaia Ur Partzuergoa v. The Argentine Republic, 2016; 710-711). Bu noktada hakem mahkemesinin kusur sorumluluğuna veya sadece özen yükümlüğüne aykırılığa dayalı bir sonuca varıp varmayacağı, somut olayda örneğin kamusal sağlık hizmetlerine yeterince bütçe ayırmak yerine özel sağlık hizmetlerini kamulaştırmak, veyahut aşı hizmetlerinin sunulmasında planlı politikalar yürütmemek gibi devlet davranışlarının, devletin sorumluluğuna neden olup olmayacağını belirleyecektir.

Özellikle günümüzün bilgiye erişim kolaylıkları dikkate alındığında, devletlerin salgınla mücadele etmek amacıyla aldıkları tedbirleri "zaruret hali" gerekçesiyle bütün bu gereklilikleri karşılayarak meşrulaştırması zor görünmekle birlikte, devletlerin bu 
The Effect of The Covid-19 Epidemic on

süreçteki davranışları ve krizi yönetmekteki başarıları hakem mahkemelerinin kararlarını kaçınılmaz olarak etkileyecektir.

\section{c) Zorunluluk (distress)}

Bir devletin, zorlayıcı bir durum içerisindeki davranışından, başka bir deyişle fiili devlete atfedilen kişinin ya da organın, kendisinin veya sorumluluğundaki kişilerin hayatlarını kurtarmak için başka türlü davranma imkânı olmadığı durumlardaki uluslararası yükümlülüğüne aykırı davranışından dolayı sorumluluğu olmayacaktır (ILC, 2001: Art. 24). Ancak söz konusu devlet, bu zorlayıcı durumun gerçekleşmesine, tek başına ya da başka faktörlerle birlikte bizzat neden olmuşsa veya söz konusu ödeve aykırı fiilin sonucu, mevcut zorlayıcı durumun sonuçlarından daha büyük tehlike yaratması muhtemel ise zorlayıc1 neden, devletin sorumluluğunu ortadan kaldırmayacaktır (Jagota, 2009: 265) ${ }^{10}$

Mücbir sebepten farklı olarak zorunluluk içerisindeki uluslararası hukuk kisişi, söz konusu tehlike nedeniyle seçme şansını kaybetmekle birlikte, tamamen rızasız hareket etmemektedir. Zaruret halinde olduğu gibi ilgili devletin, kamusal meşru çıkarlar ile uluslararası hukukun gerekleri arasında bir seçim yapma şansı da bulunmamaktadır. Sorumluluğu ortadan kaldıran bir neden olarak zorunluluk halinde korunması gereken kamusal çıkar, vatandaşlığına bakmaksızın insan ya da insanların acilen hayatlarının kurtarılmasıdır. Örneğin sivil havacılık andlaşmaları dışında bir yabancı devlet ülkesine hukuka uygun olarak girilebilmesi ancak özel izinle mümkünken, sivil hava araçlarının izinsiz girişleri, kötü hava koşulları, yön yanılması, teknik neden ya da hava aracının kaçırılması gibi nedenlerle "tehlike içinde" bulunmaları sorumluluğu ortadan kaldırır (Chicago Convention: 2006, Art. 25). Aynı şekilde yabancı devlet karasularında bulunan geminin zararsız geçiş yükümlülüğü çerçevesinde, durmaması, duraklamaması ve kıyı devletinin sularını hızlı şekilde kat etmesi gerekirken, gemi çatması, yangın, salgın hastalık gibi tehlikeli bir durum içindeyse, bu yükümlülüğünü ihlal etmesi durumu da benzer bir örneği teşkil edebilir (UNCLOS, 1982: Art. 18/2).

Covid-19 salgınının, devletlerin yargı yetkisi altındaki insan hayatlarına yönelmiş bir tehdit olması koşulunun karşılandığı söylenebilir. Burada mesele, fiili devlete atfedilen kişi ya da organın uyguladı̆̆ andlaşmasına aykırı tedbir ile hayatı tehdit altında olan kişiler arasındaki bağlantının nasıl kurulacağıdır. Bir başka deyişle, tehlike içinde karasularından geçen yabancı geminin, zararsız geçiş yükümlülüğünü ihlal etmesinin nedeni, gemideki insanların hayati çıkarları olmasına benzer şekilde, Covid-19 salgını ile mücadele ederken alınan devlet tedbirlerinin doğrudan gerekçesinin, halkın yaşamsal çıkarları olup olmadığı; kamunun yaşamsal çıkarlarının gerçekten de bu tedbirleri alan makamların elinde olup olmadığı hususunun ispatı kolay olmayacaktır. Merkezi hükümetlerin acil durumlarla baş etmek için altığı tedbirler için bu bağlantı illiyet bağı kolayca kurulabilecekken,

\footnotetext{
${ }^{10}$ Final Draft Articles with Commantaries, s. 189, para. 1; JAGOTA, SP., "State Responsibility: Circumstances Precluding Wrongfulness", s. 265.
} 
ticari ilişkileri yürüten kurumların inisiyatiflerinin doğrudan yaşamsal çıkarları ilgilendirip ilgilendirmediği her somut olayda değerlendirilmelidir. Örneğin salgının yarattığı insani kayıplar karşısında devlet organlarının başvurabileceği tek yolun, yatırımcıları etkileyen tedbirler almak olup olmadığı, bu tedbirlerin ölçülülük ilkesine uygunluğu, söz konusu tedbir alınmasaydı ilgili nüfusun bu durumdan nasıl etkileneceği ihtimali, devlet organlarının ortaya çıkan tabloyu daha da vahimleştiren tutumları gibi meseleler, kriz süresince yürütülen politikaların hakem mahkemelerince masaya yatırılmasıyla anlaşılacaktır (Paddeu ve diğ., 2020).

\section{d)}

\section{Police Powers Doktrini}

Uluslararası yatırım andlaşmaları gereği, Devletin egemen yetkileri çerçevesinde kamu sağlığının korunması amacıyla alacağı tedbirler, kural olarak yatırımcıların dolaylı kamulaştırma iddiaları bağlamında değerlendirilir. Ancak devletlerin iyi niyetli yasama faaliyetlerinin sonucu olan ve dolaylı kamulaştırma ile sonuçlanan işlemlerinden dolayı sorumlu tutulamayacağı kabul edilir (Zamir, 2017: 318).

İlk olarak 1903'te kurulan Almanya-Venezuela Komisyonu tarafından değerlendirilen Bischoff davasına konu uyuşmazlıkta, çiçek virüsü taşıyan iki yolcunun bulunduğu vagona el konulması fiilinin, salgın sırasında alınan tedbir olduğu için police powers icrası niteliğinde olup, bu fiilden dolayı devletin sorumlu olmayacağına karar verilmiştir (Bischoff Case, 1903: 420). Saluka v. Czech Republic davasında da hakem mahkemesi, kamu refahını amaçlayan iyi niyetli ve ayrımcı olmayan hukuki düzenlemelerden dolayı devletin tazminat ödemek yükümlülüğü olmadığına karar vermiştir (Saluka v. Czech Republic, 2006: 255). Benzer şekilde Philip Morris v. Uruguay, davasında hakem mahkemesi, kamu sağlığını korumak amacıyla hükümetin aldığı sigara karşıtı tedbirlerin dava konusu edilemeyeceğine, böyle tedbirlerin Uruguay'ın kamu sağlığını korumak amacını taşıyan police powers yetkileri kapsamına girdiğine, ev sahibi devletin uluslararası yükümlülüklerini ihlal etmediğine karar vermiştir. Yine Philip Morris v. Uruguay davasında hakem mahkemesi, tütün mamullerinin tek tip paketlenmesi gerekliliği konusunda, kamu sağlığının korunması gibi konularda ulusal ihtiyaçların karşılanması amacıyla alınan devlet tedbirlerinin zorunluluğunu aynı gerekçe ile vurgulamıştır (Philip Morris v. Uruguay, 2016, 399). Ancak burada ev sahibi devletin kamu sağlığını korumak amacıyla aldığı tedbirlerin, iyi niyetli, ayrım gözetmeyen, ölçülülük ilkesine uygun olmasını gerekliliğini unutmamak gerekmektedir (Sebastiani, 2020).

\section{Sonuç}

Covid-19 salgını, devletleri hem milyonlarca insanın hayatını korumak hem de ekonomilerini ayakta tutmak için bir takım acil durum önlemleri almaya zorlamıştır. Bu önlemlerin pek çoğu, yukarıda da özetlendiği üzere, yatırım uyuşmazlıkları doğurmaya müsait sert ve müdahaleci niteliktedir. Devletlerin Covid-19 salgını ile mücadele süreçlerinde aldığı tedbirlere ilişkin tahkim yargılamalarında, ilgili devlet, iyi niyet, ölçülülük ve ayrım gözetmeme ilkelerine uyduğu sürece, hakem mahkemelerinin bu tedbirleri hukuka uygun olarak değerlendirmesi muhtemeldir. Bununla birlikte, konunun 
hem kamu sağlığı hem de ekonomik ilişkiler bakımından önemi haiz olması, muhtemel devlet-yatırımcı uyuşmazlıklarının çözüm süreçlerini ve hakem mahkemelerinin, devletlerin düzenleyici yetkilerinin kapsamı üzerine uluslararası yatırım hukuku bakımından önemli tespitlerini içerecek olması bakımından yakından izlenmesi gerekmektedir.

Hem geçmiş tarihli yargı kararlarına dayanarak hem de modern uluslararası yatırım andlaşması hükümleri ve bu konudaki sivil toplum çalışmalarından esinlenilerek, Covid-19 salgını ile mücadele tedbirlerinin yatırım uyuşmazlıklarının çözümüne etkisine ilişkin olarak, bazı uluslararası inisiyatiflerin de gündeme getirdiği gibi, yatırım andlaşmalarının askıya alınması ya da en azından andlaşmalardan kaynaklanan tahkim iddialarının askıya alınması ihtimali, halen devam eden ve yukarıda değinilen Glencore Finance v. Bolivia yargılamasındaki hakem mahkemesinin ara kararına bakılacak olursa, gelecekte reddedilecek gibi görünmektedir. Ancak böyle bir gidişatın, uluslararası yatırım uyuşmazlıklarının çözümü süreçlerini, gelecekte yerel düzeye kaydıracağ 1 da öngörülmektedir (Danish, 2021: 2). Zira özellikle gelişmekte olan devletler, uluslararası yatırımcılar ile aralarındaki uyuşmazlıkların etkili çözümü için mevcut yerel ve bölgesel kurumlarının güçlendirmenin yollarını aramaktadırlar. Dolayısıyla ICSID ya da Daimi Hakem Mahkemesi gibi tahkim kurumları yerine, örneğin Pakistan'da bulunan Lahore Uluslararası Yatırım ve Ticari Tahkim Merkezi, Ruanda'da bulunan Kigali Uluslararası Tahkim Merkezi ya da Costa Rica'da bulunan Uzlaştırma ve Tahkim Merkezi gibi daha bölgesel nitelikteki uyuşmazlık çözüm merkezlerine rağbet artabilecektir. Diğer yandan yatırımcılar ve ev sahibi devletler arasındaki etkileşimin bu gidişatı değiştireceğini öngören ve hakem mahkemelerinin bu bakış açısını eleştiren bazı yazarlar ise hakem mahkemelerinin yatırım tahkimi süreçlerinde yargılamanın bütünlüğünü korumak adına, temel insan hakları mülahazalarını görmezden gelerek, yatırımcı-devlet ilişkilerini de geleceğe dönük olarak olumsuz etkilediğini belirtmektedir (Luque-Macías, 2021:231)

Aslında binlerce uluslararası yatırım andlaşması ile örülen yabancı doğrudan yatırım ağında, yatırımcı-devlet uyuşmazlıklarından kaynaklanan iddiaların tahkim yargılaması konusu olabilmesi riski her zaman mevcuttur. Salgın süreci ile bağlantılı olarak muhtelif hükümet-dışı kuruluşlar ve inisiyatiflerin, bu tür yargılama ihtimallerini azaltmak için şirketlerin ev sahibi devletlere uluslararası yatırım andlaşmalarından kaynaklanan uyuşmazlıklar nedeniyle tahkim taleplerini askıya almaları çağrısı, elbette devletler arasında müzakere edilerek muhtelif hükümetlerarası kuruluşlar nezdinde gündeme alınabilecektir. Ancak bu taleplerin mahkemelerce reddedilme olasılığ karşısında, yatırım andlaşmalarının hazırlanması süreçlerinde, andlaşmalardaki mücbir sebep hükümlerinin, mücbir sebep niteliğindeki olaylar yanında, bu olayların muhtemel etkilerini de içerecek şekilde formüle edilmesi, gelecekte ev sahibi devletlerin böyle süreçlerle baş etme kapasitesini artırabilecektir. Kamu sağlığına ilişkin devlet politikaları ile uluslararası yatırım andlaşmaları arasındaki uyumu yakalayabilmek için gelecekteki yatırım andlaşmalarının bir yandan sağlık sektöründeki yabancı doğrudan yatırımları kolaylaştıran ve teşvik eden, diğer yandan ev sahibi devletin kamu sağlığını korumaya yönelik düzenlemeler yapma hakkını koruyacak güvenceler temin eden veya 
mevcutları güçlendiren hükümler içermesi mümkündür. Zira bir yatırımın sürdürülebilirliğini sağlamak, özellikle de yatırımcıların sağlık sorunlarının süresini ve kapsamını öngöremeyeceği bir sektör olan sağlık alanında, önemli bir gerekliliktir. Yatırımcılar ve ev sahibi devletler arasındaki uyuşmazlıklar, sağlık hizmetleri, ilaç, tanılama, aşı sektörlerini de içine alan, halk sağlığını tehdit eden yeni sorunları doğurmaktadır. $\mathrm{Bu}$ nedenle yatırımcılar ile ev sahibi devletler arasındaki uyuşmazlıkların çözümü süreçlerinin nasıl yürütüldüğü meselesi, gelecekteki benzer muhtemel krizlere karşı her iki tarafı da daha hazırlıklı olmaya zorlayacaktır.

Hali hazırda başvurusu yapılan tahkim yargılamalarında ise hakem mahkemelerinin varsa öncelikle ilgili yatırım andlaşmasındaki istisnai hükümlere göre değerlendirme yapacağı; bu tür hükümler yoksa uluslararası teamül hukuku ve hukukun genel ilkelerinden hareketle, yatırımcının ekonomik hakların halel getiren ilgili devlet tedbirlerinin meşruiyetini "zaruret hali" (necessity) kapsamında değerlendirmesi olasıdır. Hakem mahkemelerinin, devletin sorumluluğunun doğmasını engelleyen bütün koşulları değerlendirirken, somut uyuşmazlıkta iyi niyetli, ayrım gözetmeyen, ölçülülük ve şeffaflık ilkelerine uygunluk kriterlerini karşılayan tedbirlerin meşruiyetine karar vermesi beklenmektedir. Gelecekte tefhim edilen kararlar ise devletin uluslararasi sorumluluğunun istisnalarını yeniden yorumlayacak ve bu konuda BM Uluslararası Hukuk Komisyonunun kodifiye ettiği teamül hukuku kurallarının yeni yorumlarını gündeme getirebilecektir.

Ancak her halükarda, Covid-19 ile ilgili tahkim yargılamalarında, hakem mahkemelerinin bir yandan devlet önlemlerinin odağındaki kamu sağlığına ilişkin mülahazaları, diğer yandan da yabancı yatırımcıların haklarını dengelemeye çalışırken, yatırım tahkim yargılaması bağlamında devletin düzenleyici yetkilerinin kapsamını bir kere daha tartışmaya açacakları ve belki de yatırım uyuşmazlıklarının çözümünde daha yerel veya bölgesel kurumsallaşma çabalarını hızlandıracağı öngörüsünde bulunulabilir. $\mathrm{Bu}$ konuda uluslararası teamül hukukunun gelişimini ve daha fazla kurumsallaşma örneklerini görmek için hakem mahkemelerinin kararlarını beklemek gerekmektedir.

\section{Kaynakça}

\section{Kitap ve Makaleler}

Augenblick, M. \& Rousseau, A. B. (2012). Force Majeure in Tumultuous Times: Impracticability as the New Impossibility. Journal of World Investment. \& Trade, 13, 59-75.

Baklacı, P. (2008). Uluslararası Yatırımlarda "Dolaylı Kamulaştırma" ve Düzenleyici Yetkiler. Milletlerarası Hukuk ve Milletlerarası Özel Hukuk Bülteni, 28(1-2), 125. 
Brower, C. N. \& Schill, S. W. (2008). Is Arbitration a Threat or a Boom to the Legitimacy of International Law. Chicago Journal of International Law, 9, 471498.

Borman, Y. R. (2020). Covid-19 \& International Investment Protection. https://www.shearman.com/perspectives/2020/04/covid-19-internationalinvestment-protection $(19 / 08 / 2021)$.

Chitapain, L. (2021). Are Multinational Companies Owed Compensation For COVID19 Emergency Measures?. The Monitor, Canadian Center for Policy Alternatives. https://monitormag.ca/articles/are-multinational-companies-owedcompensation-for-covid-19-emergency-measures (18/08/2021).

Çal. S (2009). Uluslararası Yatırım Tahkimi ve Kamu Hukuku İlişkisi. Ankara: Seçkin Yayınları.

Danish (2021). Could Covid-19 Trigger 'localizing' of International Investment Arbitration?, Investment Policy Brief, 21, https://www.southcentre.int/wpcontent/uploads/2021/04/Investment-PB-21.pdf (18/08/2021).

Davitti, D., Ho, J., Vargiu P., Vastardis A. (2020). Covid-19 and the Precarity of International Investment Law. IEL Collective, https://medium.com/ielcollective/covid-19-and-the-precarity-of-international-investment-law-

c9fc254b3878 (17/08/2021).

Dolzer R. (2005). The Impact of International Investment Treaties on Domestic Administrative Law. New York Journal of International Law and Politics, 37, 953-972.

Firoozmand, M. R. \& Zamani, J. (2017). Force Majeure in International Contracts: Current Trends and How International Arbitration Practice is Responding. Arbitration International, 33, 395-415.

Fry, J. D. \& Repousis, O. G. (2016). Towards a New World for Investor-State Arbitration Through Transparency. New York Journal of International Law and Politics, 48, 795-865.

Giray, F. K. (2013). Milletlerarası Yatırım Tahkiminde Kamulaştırmadan Doğan Tazminat ve Tazminatın Hesaplanmasında Kullanılan Yöntemler. 2. Baskı, İstanbul: Beta Basımevi.

Gözübüyük, Ş. \& Tan, T. (2013). İdare Hukuku, Güncelleştirilmiş 9. Bası, Ankara: Seçkin Yayınları. 
Guntrip, E. (2016). Self-Determination and Foreign Direct Investment: Reimagining Sovereignty in International Investment Law. International and Comparative Law Quarterly, 65(4), 829-857.

Jagota, S. P. (1985). State responsibility: Circumstances Precluding Wrongfulness. Netherlands Yearbook of International Law, 16, 249-277.

Kiraz, Ş. E., \& Üstün, E. Y. (2020). Covid-19 and Force Majeure Clauses: An Examination of Arbitral Tribunal's Awards. Uniform Law Review, 25(4), 437465.

Kowalski, P. (2020). Will the post-Covid world be less open to foreign direct investment?. Editors: Baldwin, R., ve Evenett, S., COVID-19 and Trade Policy: Why Turning Inward Won't Work, 131-149, CEPR Press.

Ostrove, M., Brown de Vejar, K., / Sanderson, B. (2020). Covid-19 - A Legitimate Basis for Investment Claims?. https://www.dlapiper.com/en/europe/insights/publications/2020/04/covid-19-alegitimate-basis-for-investment-claims/ (19/08/2021).

Paddeu, F. \& Parlett, K. (2020). Covid-19 and Investment Treaty Claims. Kluwer Arbitration Blog, http://arbitrationblog.kluwerarbitration.com/2020/03/30/covid19-and-investment-treaty-claims/ (10/08/2021).

Pazarc1, H. (2013). Uluslararası Hukuk. Ankara: Turhan Kitabevi.

Sanderson, C. (2020). Mexico Faces Potential Claims Over Pandemic Response. Global Arbitration Review, https://globalarbitrationreview.com/coronavirus/mexicofaces-potential-claims-over-pandemic-response (10/06/2021).

Sanderson, C. (2020). Peru Warned of Potential ICSID Claims over Covid-19 Measures. Global Arbitration Review, https:/globalarbitrationreview.com/coronavirus/peru-warned-of-potential-icsidclaims-over-covid-19-measures (18/08/2021).

Schill, S. W. (2019). The European Union's Foreign Direct Investment Screening Paradox: Tightening Inward Investment Control to Further External Investment Liberalization. Legal Issues of Economic Integration 46(2), 105-128.

Schmidt, S. (2020). Austria: Thoughts on the Legitimacy, Sustainability and Future of ISDS in Times of Crisis. Mondaq, https://www.mondaq.com/austria/operationalimpacts-and-strategy/988580/thoughts-on-the-legitimacy-sustainability-andfuture-of-isds-in-times-of-crisis (18/08/2021). 
Sebastiani, F. (2020). Investor-State Disputes during the Covid-19 Pandemic: Balancing Public Health Concerns and Foreign Investors' Rights, Sciences Po Law Review, https://www.revuedesjuristesdesciencespo.com/index.php/2020/11/13/investorstate-disputes-during-the-covid-19-pandemic-balancing-public-health-concernsand-foreign-investors-rights/ (10/08/2021).

Wexler, J. (1987). Rainbow Warrior Affair: State and Agent Responsibility for Authorized Violations of International Law. Boston University of International Law Journal, 5., 389-412.

Zamir, N. (2017). The Police Powers Doctrine in International Investment Law. Manchester Journal of International Economic Law, 14, 318-337.

\section{Yargı Kararları, Uluslararası Kuruluşların Raporları, Andlaşma Metinleri}

African Union The African Union's Declaration on Covid-Related ISDS Risks (2021) Annex V: Draft Declaration on The Risk of Investor-State Dispute Settlement With Respect To Covid-19 Pandemic Related Measures. https://www.iisd.org/articles/african-union-ministerial-declaration-covid-relatedisds-risks-why-it-matters-now $(18 / 08 / 2021)$.

Agreement Between The Government of The Republic of Turkey and The Government of The People's Republic of China Concerning The Reciprocal Promotion and Protection of Investments (2020). https://investmentpolicy.unctad.org/international-investment-agreements $(19 / 08 / 2021)$.

Belgium-Luxembourg Economic Union Model BIT 2019. https://investmentpolicy.unctad.org/international-investment-agreements/modelagreements (19/08/2021).

Bischoff Case, German-Venezuelan Commission, Reports of International Arbitral Awards,

1903, Vol. X, 420-421.

Canada Model BIT 2021. https://investmentpolicy.unctad.org/international-investmentagreements/model-agreements (19/08/2021).

Glencore Finance (Bermuda) Ltd v. The Plurinational State of Bolivia (PCA Case No. 2016-39), Procedural Order No. 11, 5 May 2020. https://www.italaw.com/cases/5941 (19/08/2021).

Glencore Finance (Bermuda) Limited v. Plurinational State of Bolivia (PCA Case No. 2016-39), Procedural Order No: 10, $20 \quad$ January 2020. https://www.italaw.com/cases/5941 (19/08/2021). 
ICC Force Majeure Clause, International Chamber of Commerce, Publication No. 650, Paris 2002, https://iccwbo.org/content/uploads/sites/3/2017/02/ICC-ForceMajeure-Hardship-Clause.pdf (19/08/2021).

Impregilo S.p.A. v. Argentine Republic, ICSID Case No. ARB/07/17, Award of 21 January 2011, https://www.italaw.com/cases/554_(19/08/2021).

International Court of Justice, Gabčíkovo-Nagymaros Project (Hungary/Slovakia), Judgment of 25 September 1997, https://www.icj-cij.org/en/case/92 $(19 / 08 / 2021)$.

International Institute for Sustainable Development (IISD) (2020). Proposed Text And Commentary: Agreement for the Coordinated Suspension of Investor-State Dispute Settlement With Respect to COVID-19- Related Measures and Disputes. https://www.iisd.org/system/files/2021-02/suspension-isds-covid-19-en.pdf $(18 / 08 / 2021)$.

Investment Policy Hub (2021). Most Recent Hubs. IIA's.https://investmentpolicy.unctad.org/international-investment-agreements $(18 / 08 / 2021)$.

Italy Model BIT 2020. https://investmentpolicy.unctad.org/international-investmentagreements/model-agreements (19/08/2021).

Korea-Japan BIT (2003). Agreement Between The Government of The Republic of Korea and The Government Of Japan for The Liberalisation, Promotion and Protection of Investment. https://investmentpolicy.unctad.org/internationalinvestment-agreements/model-agreements (19/08/2021).

Marfin Investment Group Holdings S.A., Alexandros Bakatselos and others v. Republic of Cyprus (ICSID Case No. ARB/13/27), Award of 26 July 2018.

National Grid plc v. The Argentine Republic (UNCITRAL), Award of 3 November 2008, https://www.italaw.com/cases/732 (19/08/2021).

Netherlands Model BIT 2019. https://investmentpolicy.unctad.org/internationalinvestment-agreements/model-agreements (19/08/2021).

Open-Ended Intergovernmental Working Group on Transnational Corporations and Other Business Enterprises with Respect to Human Rights (2020). OEIGWG Chairmanship Second Revised Draft of Legally Binding Instrument To Regulate, in International Human Rights Law. The Activities of Transnational Corporations and Other Business Enterprises, 
https://www.ohchr.org/Documents/HRBodies/HRCouncil/WGTransCorp/Sessio n6/OEIGWG_Chair-

Rapporteur_second_revised_draft_LBI_on_TNCs_and_OBEs_with_respect_to_ Human_Rights.pdf (18/08/2021).

Philip Morris Brands Sàrl, Philip Morris Products S.A. and Abal Hermanos S.A. v. Oriental Republic of Uruguay, ICSID Case No. ARB/10/7. Award of 8 July 2016.

Saluka Investments B.V. v. The Czech Republic, Partial Award of 17 March 2006, https://www.italaw.com/cases/documents/963 (19/08/2021).

S.D. Myers, Inc. v. Government of Canada (UNCITRAL), Partial Award of 13 November 2000, https://www.italaw.com/cases/969 (19/08/2021).

Teinver S.A., Transportes de Cercanías S.A. and Autobuses Urbanos del Sur S.A. v. The Argentine Republic (ICSID Case No. ARB/09/1), Award of 21 July 2017.

Uluslararası Hukuka Aykırı Eylemlerinden Dolayı Devletin Sorumluluğu" Taslak Maddeleri (Final Draft Articles), Draft Articles on Responsibility of States for Internationally Wrongful Acts, Text adopted by the International Law Commission at its fifty-third session, in 2001, and submitted to the General Assembly as a part of the Commission's report covering the work of that session (A/56/10).

United States-Mexico-Canada Agreement-USMCA (2020). https://ustr.gov/tradeagreements/free-trade-agreements/united-states-mexico-canada-agreement $(19 / 08 / 2021)$.

Urbaser S.A. and Consorcio de Aguas Bilbao Bizkaia, Bilbao Biskaia Ur Partzuergoa v. The Argentine Republic, ICSID Case No. ARB/07/26, Award of 8 December 2016 https://www.italaw.com/cases/1144_(19/08/2021).

International Civil Aviation Organization (ICAO), Convention on Civil Aviation (Chicago Convention), 7 December 1944, (1994) 15 U.N.T.S. 295

United Nations Convention on the Law of the Sea (UNCLOS),10 December 1982, 1833 U.N.T.S. 397.

United Nations Conference on Trade and Development (UNCTAD) Investment Policy Monitor No. 24 (UNCTAD/DIAE/PCB/INF/2021/2), February 2021, https://unctad.org/system/files/official-document/diaepcbinf2021d2_en.pdf $(10 / 06 / 2021)$.

UNCTAD World Investment Report 2021 (UNCTAD/WIR/2021), https://unctad.org/system/files/official-document/wir2021_en.pdf_(10/06/2021). 